\title{
CORRUPTION AND FRAUD DETECTION THROUGH FORESIC ACCOUNTING PRACTICES IN KURDISTAN REGION OF IRAQ
}

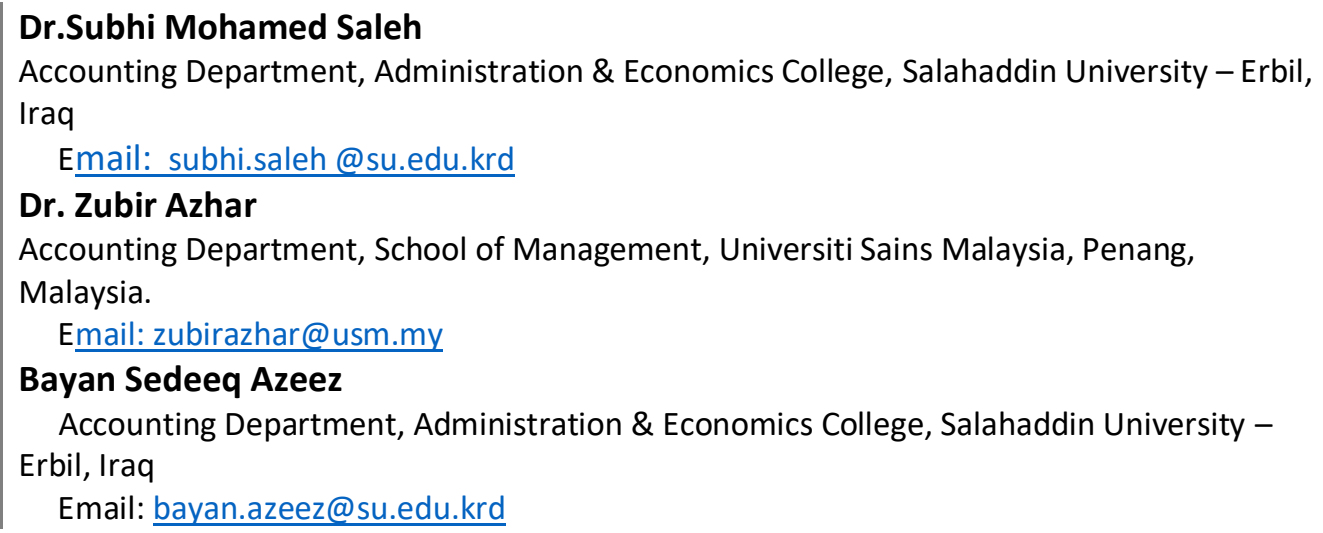

\section{Bayan Sedeeq Azeez}

Accounting Department, Administration \& Economics College, Salahaddin University Erbil, Iraq

Email: bayan.azeez@su.edu.krd

\section{ARTICLE INFO}

\section{Article History:}

Received: 8/1/2020

Accepted: $15 / 2 / 2020$

Published: Winter 2020

\section{Keywords:}

Forensic

accounting,

Forensic

accounting

practices,

detection, Corruptions,

Financial fraud.

\section{ABSTRACT}

This paper aims to explore the importance and the role of forensic accounting practices in detecting (and preventing) corruption and fraud; and to identify the factors that hinder the adoption of forensic accounting practices in Kurdistan Region, Iraq. To achieve the objectives of the study was developed questionnaire included (24 questions) distributed on 47 academic professionals in the Kurdistan Region Iraq, the researchers reached a number of conclusions after analyzing questionnaire's questions. The most important of these conclusions There is a role Forensic Accounting in combating fraud and financial corruption in the Kurdistan Region and there are many factors that hinder the application of 
Doi: 10.25212/lfu.qzj.5.1.6
Forensic Accounting in the Kurdistan Region. The researchers also made a number of recommendations, in view of the importance of Forensic Accounting, therefore, researchers recommend increasing interest in it in the school curriculum and incorporating this aspect in accounting education so that the graduate to be familiar with it and the necessity for the Kurdistan Regional Government to build an effective monitoring system based on Forensic Accounting services that takes it upon itself to preserve both the rights and the financial authority.

\section{Introduction}

In any developed economies, it is not uncommon that the control of economic activities is both strong and systematic, and hence, resulting in little number of reported cases of illegal practices involving business corruption and financial fraud, which emerge from scandalous activities (Avnimelech, Zelekha, \& Sharabi, 2014). Nevertheless, one should not dismiss the idea that corruption and fraud are endemic and are being considered as greasing of economic wheels as compared to putting them into the sand. While one might argue that corruption and fraud have a positive role to play in influencing economic activities within specific countries at particular point in time, the major findings of the existing studies have revolved around some negative impacts on the ultimate economic growth of certain countries (Bardhan, 1997; d'Agostino, Dunne, \& Pieroni, 2016). Indeed, as indicated by d'Agostino et al. (2016), it is less effective for countries of the developing economies to put the mechanisms for detecting and 


\section{QALAAI ZANISTSCIENTIFIC JOURNAL}

A Scientific Quarterly Refereed Journal Issued by Lebanese French University - Erbil, Kurdistan, Iraq

Vol. (5), No (1), Winter 2020

ISSN 2518-6566 (Online) - ISSN 2518-6558 (Print)

preventing corruption and fraud at the forefront when the public sector agencies' efficiency and the country-specific financial management systems are being criticized for being less functional in dealing with matters related to business corruption and financial fraud.

As argued by Avnimelech et al. (2014), both corruption and financial fraud have the potential to affect the growth of the business firms as their existence is significant economically within regions. The level of corruption and fraud varies from region to region and/or state to state in similar ways the wages and the tax rates differ in the US. Among the challenges for those business firms which are working in different regions is how to understand and accept the level of local corruption and fraud. However, the limit of corruption and fraud for the business firms is not just to assess but also to focus on its ultimate impact on the operational efficiency (De Rosa, Gooroochurn, \& Görg, 2010; Gaviria, 2002; Habib \& Zurawicki, 2002). To operate effectively, business firms must understand corruption and fraud implications and various factors associated with these malpractices given that they are now intensely discussed in the extant literature (see, e.g., Rubin, 2018; Nwanyanwu, 2018; Bhasin, 2015; Alabdullah, Alfadhl, Yahya, \& Rabi, 2014; Akyel, 2012).

To contain corruption, sufficient amount of reliable information must be made available which will result in effective and efficient decision-making processes in business firms. With the technologically-infused advancement and complexity in accounting transactions, fraudulent activities have been attempted by many parties, including accountants in the presence of the imputed approval from top management and the support from employees. At recent time, fraudulent conducts have increased gradually; making the detection (and prevention) processes much more difficult with the ultimate disagreement between business firms and their key stakeholders like 


\section{QALAAI ZANISTSCIENTIFIC JOURNAL}

A Scientific Quarterly Refereed Journal Issued by Lebanese French University - Erbil, Kurdistan, Iraq

Vol. (5), No (1), Winter 2020

ISSN 2518-6566 (Online) - ISSN 2518-6558 (Print)

employees, government and credit institutions. Malicious experts can manipulate accounting data, notebook, invoices and other documentary evidences or the value of sales can be increased or decreased as per managers' demands and desires. For such matter, the support from experts is very much needed to address compelling issues associated with corruption and fraud (De Rosa et al., 2010). As per the view point of American Institute of Certified Public Accountant (AICPA), this support is called "professional support" which purports the idea that the accountancy profession should be a positive force in fighting against corruption and fraud. Such force includes developing more transparent and complete information and enforcing the recognized accounting standards to enhance the quality of information provided.

To consider the accuracy of information in the financial statements, one should not undermine the importance of forensic accounting. In more recent years, the US, the UK and Canada have established forensic accounting as a new occupation to detect the records of accounting frauds (Akyel, 2012). Forensic accounting is normally performed by Certified Public Accountants (CPAs) whose prime responsibility is to conduct investigations, inspections and auditing to reach the ultimate truth with regard to information communicated to relevant stakeholders. The examination of accounting records is mainly aimed at protecting the public (particularly shareholders') interests (Akyel, 2012; Crumbley, 1995, 2003). In various third world countries like Nigeria and other developing economies, financial crimes, corruptions and frauds have affected the citizens negatively as it is down to the root level. The alarming and devastating issue is that both corruption and fraud are under intense scrutiny in developing countries and for this purpose the role of forensic accounting is therefore deemed important to be considered in fighting against these malpractices (Kasum, 2009). However, it is also acknowledged that the concept of forensic accounting to detect and control the frauds 
is in the rudimentary phase (Bhasin, 2015; Okoye, 2009). This is especially the case of Iraq, particularly in the region of Kurdistan (Rubin, 2018) and thus, pose a huge challenge for the country to combat such malpractices.

\section{Problem Statement}

The problem of the contemporary business environment, in the field of accounting might have an in-depth understanding of governance and accountability issues. There is an increasing demand in almost all the business sectors for the accountants who can work under the framework of forensic accounting for the detection and control of frauds (Alabdullah et al., 2013; Wang, Lee, \& Crumbley, 2016).

Traditional accounting has a lack of modern techniques and tools which can help accountants to identify and control the malpractices in business firms. Therefore, forensic accounting has secured much attention amongst accountants given its modern approaches, structured guidelines and techniques, and support systems (Bhasin, 2015; Nwanyanwu, 2018). Thus, this paper aims at addressing the problem of how to detect and control the corruption and fraud activities by relating to the need for establishing forensic accounting practices in enhancing the detection (and prevention) of corruption and fraud in Iraqi corporations operating in the Kurdistan Region, Iraq. Up to now, the role of forensic accounting in detecting (and preventing) fraud and corruption especially within the context of Iraq is not well addressed. To remedy such gap, this paper has provided an important perspective on the development of forensic accounting practices in this context.

\section{Research Questions}




\section{QALAAI ZANISTSCIENTIFIC JOURNAL}

A Scientific Quarterly Refereed Journal Issued by Lebanese French University - Erbil, Kurdistan, Iraq

Vol. (5), No (1), Winter 2020

ISSN 2518-6566 (Online) - ISSN 2518-6558 (Print)

Specifically, this paper seeks to find answers for the following research questions:

1. What is the role of forensic accounting practices in detecting (and preventing) corruption and fraud in the Kurdistan Region, Iraq? Why and how are they important?

2. What are the factors that influence the use of forensic accounting practices in detecting and preventing financial fraud and corruption in the area?

\section{Research Hypothesis}

1. There is no statistically significant relationship at level $(\alpha \leq 0.05)$ between use of the Forensic Accounting and the detection and combating of the following corruption and financial fraud practices in the Kurdistan Region of Iraq

2. There is no statistically significant relationship at level $(\alpha \leq 0.05)$ between Factors that hinder the use of Forensic Accounting to detect and combat corruption and financial fraud practices in the Kurdistan Region of Iraq.

\section{Purpose of the Study}

This paper has the following aims:

1. To explore the importance and the role of forensic accounting practices in detecting (and preventing) corruption and fraud.

2. To identify the factors that hinder the adoption of forensic accounting practices. 


\section{$\underline{\text { Research Methods }}$}

This paper attempts to assess the need for establishing forensic accounting practices in the Kurdistan Region, Iraq and for exploring the role played by such practices in enhancing the detection (and prevention) of corruption and fraud with specific reference to Iraqi corporations. It also attempts to identify the environmental factors that hinder the adoption of forensic accounting practices in the Kurdistan Region, Iraq. These are all examined by using the literature search and analyzing the unpublished records. The agency theory is a way to see the world which is bounded by the social values and capable of influencing on the perception of people on the organization can visualize by the annual capital reporting procedure (Cormier \& Gordon, 2001; Magness, 2006). The capital reporting has the two prolonged effect in the social responsibilities and shaping the stakeholder's perception on the organization (Gray et al., 1995). On that note several past studies socials concerned also played the greater role in the availability and issuing of the annual reports. Prior research such as Brennan and Solomon (2008) and Whiting and Woodcock (2011) have suggested that agency theory has the direct and indirect link to the transparency of financial reporting quality which would be main resource to present the financial performance of any business firms. However, in this paper, we argue that corruption and fraud, as well as the environmental factors may exert significant influences on the overall forensic accounting practices in a country. Indeed, these are arguably the most significant forces that shape how forensic accounting is designed to curb the malpractices, particularly within the fraternity of fraud investigation process by the relevant authorities.

\section{framework of the study}




\section{QALAAI ZANISTSCIENTIFIC JOURNAL}

A Scientific Quarterly Refereed Journal Issued by Lebanese French University - Erbil, Kurdistan, Iraq

Vol. (5), No (1), Winter 2020

ISSN 2518-6566 (Online) - ISSN 2518-6558 (Print)

In order to carry out the analysis the researchers designed specific model to include all the variables. Figure (1) illustrates the relationships of these variables

Dependent variable

\section{Forensic Accounting Practices}

Factors that hinder the use of Forensic Accounting
Independent variable

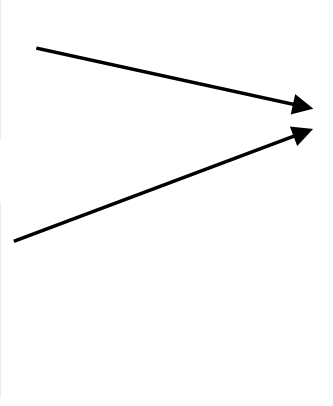

Figure 1: Conceptual framework of the study

Figure 1 above shows their relationships in terms of the reaction of forensic accounting (of relevant authorities) depends entirely on the magnitude of business malpractices and environmental factors.

\section{Findings \& Discussion}


Generally, there are many countries in the Middle East that have been subject to dreadful threat with regard to business malpractices (i.e. corruption and fraud). As reported by Al-Sultan, Sabri, and Mardan (2015, p.2), “...the utmost and worst condition is recognized in the last decade of Iraqi new era". Maxime (2013) reported the regional discrepancies over corruption and fraud cases (bribery in specific) $-29 \%$ of individuals and business firms in Baghdad, Iraq having reported paying bribes, in comparison to only $3.7 \%$ in Kurdistan.

As a developing economy, Iraq, as per the report of Transparency International, has captured the top position in the list of financially corrupt region (Alabdullah et al., 2014). Out of 175 countries, Iraq got the position of 166 as least corrupted country. The average corruption rank in Iraq is 161.29 from 2003 to the year 2016 in which it got the highest rank of 178 in 2007 and low level of 113 in 2003. In the region of Kurdistan in Iraq particularly, Rubin (2018) has reported that the corruption and fraud activities have been occurring and there appear to be serious attempts to combat this problem.

The financial crime in Iraq is characterized by secrecy and mystery that resulted a huge damage to the national economy committed by senior governmental officials and influential politicians. Interestingly, the government has established professional association (or body) of forensic accounting to expand the responsibility of accounting to not only limited to the auditing functions but to more advanced functions of investigation of financial fraud cases, and to enhance the role of forensic accounting in detecting (and preventing) corruption and fraud activities. These can be achieved by improving educational curricula in accounting in terms of introducing forensic accounting as a new discipline that will enhance the awareness of the forensic role in fighting corruption. Indeed, some higher learning institutions have introduced forensic accounting modules in their curriculum to provide training and skills needed to address issues (and raise awareness) concerning corruption and fraud in business practices (Hadi, Abed, \& Kadim, 2018). 
The cases of corruption and fraud activities in the Kurdistan Region, Iraq carry very unique issues that no other crime poses, and investigator starts their queries by posing such questions as whether or not the activities are identity theft, insurance fraud or malpractices executed for some personal benefits. To properly investigate any corruption and fraud, forensic accounting should be based on the key points like create a well investigation plan, repeated interview with the victim, collecting and securing the key evidences and professionalism of investigation.

In Iraq, corruption is considered as one of the most problematic and tough misconduct to investigate. Under normal circumstances, there is no scene or fingerprints for such crime and by its nature it is considered as the secret crime. Even in some cases there are some eye witnesses, most of chance that they too are the parties of corruption. However, for the investigation of corruption there is a significant need to adopt the prerequisites for the effectiveness of investigation. For instance, the concept of government level corruption and its investigation can be embarrassing for the government. So, the independence of the investigation team is much important. Besides the adequate power of investigation, resources and confidentially and multilevel mutual assistance and effective complaint systems are much important.

According to an Iraqi government agency's unpublished documents, the application of forensic accounting tools and techniques in the prevention and detection of fraud in Iraq is also influenced by some factors. Such factors include the following:

1. The poor control and checking system;

2. Inadequate training which ultimately lead to poor governance; and

3. Lack of knowledge or experience of the staff members. 


\section{QALAAI ZANISTSCIENTIFIC JOURNAL}

A Scientific Quarterly Refereed Journal Issued by Lebanese French University - Erbil, Kurdistan, Iraq

Vol. (5), No (1), Winter 2020

ISSN 2518-6566 (Online) - ISSN 2518-6558 (Print)

The significance of forensic accounting can be viewed in the sense that it is relatively new specifically in the Kurdistan Region of Iraq. This suggests that accounting professionals and practitioners can conclude the behavior of using forensic accounting tools and techniques for the detection and investigation of frauds.

\section{Description of the study population and the sample}

Form questionnaire was distributed to a sample of (47) researched in academic (Accounting) at universities and institutes in Kurdistan Region of Iraq, and the results were as follows:

1: description of the General Information researches:

The general information of the researches is summarized in Table (1).

Table (1)

Description of the General Information researches

\begin{tabular}{|c|c|c|}
\hline General Information & Frequency & Percent \\
\hline \multicolumn{3}{|l|}{ 1. Work place: } \\
\hline Universities & 30 & 63.8 \\
\hline Institutes & 17 & 36.2 \\
\hline \multicolumn{3}{|l|}{ 2.Scientific Certificate: } \\
\hline Master Degree & 36 & 76.6 \\
\hline $\mathrm{PhD}$ & 11 & 23.4 \\
\hline \multicolumn{3}{|l|}{ 3.Scientific Title: } \\
\hline Assistant Teacher & 14 & 29.8 \\
\hline Teacher & 23 & 48.9 \\
\hline Assistant Professor & 9 & 19.1 \\
\hline Professor & 1 & 2.1 \\
\hline \multicolumn{3}{|l|}{ 4.Years of Experience: } \\
\hline From 1 year -5 years & 13 & 27.7 \\
\hline From 6 years -10 years & 12 & 25.5 \\
\hline From 11 years -15 years & 8 & 17 \\
\hline
\end{tabular}




\section{QALAAI ZANISTSCIENTIFIC JOURNAL}

A Scientific Quarterly Refereed Journal Issued by Lebanese French University - Erbil, Kurdistan, Iraq

Vol. (5), No (1), Winter 2020

LF U

ISSN 2518-6566 (Online) - ISSN 2518-6558 (Print)

\begin{tabular}{|c|c|c|c|}
\hline & From 16 years -20 years & 4 & 8.5 \\
\cline { 2 - 4 } & 21 years and more & 10 & 21.3 \\
\hline
\end{tabular}

Table (1) shows that the research sample included for work place, $63.8 \%$ of university academics compared to $36.2 \%$ of institutes, and scientific certificate, $76.6 \%$ of master's degree compared to $23.4 \%$ of the PhD. Scientific title, $29.8 \%$ of assistant teacher, $48.9 \%$ of teacher, $19.1 \%$ of assistant professor and $2.1 \%$ of professor. Finally years of experience, $27.7 \%$ of (from 1 year -5 years), $25.5 \%$ of (from 6 years -10 years), $17 \%$ of (from 11 years -15 years), $8.5 \%$ of (from 16 years -20 years) and $21.3 \%$ of ( 21 years and more).

\section{2: description of the research variables and diagnosis:}

Will be in this analysis to the questionnaire which included (2) variables, Answers of researches were summarized her through the tables of the following:

The First variable: Forensic Accounting leads to the detection and combating of the following corruption and financial fraud practices in Kurdistan Region of Iraq: The arithmetic means of each of the equation from questionnaire study evaluated by Likert scale (Totally not agree $=1$, Not agree $=2$, Not sure $=3$, Agreed $=4$, and totally agree $=5$ ). On this basis, the level question means according to the importance and the degree of agreement with the hypothesis of the research and summarized in the following table:

Table (2)

Descriptive Statistics for First variable 


\section{QALAAI ZANISTSCIENTIFIC JOURNAL}

A Scientific Quarterly Refereed Journal Issued by Lebanese French University - Erbil, Kurdistan, Iraq

Vol. (5), No (1), Winter 2020

ISSN 2518-6566 (Online) - ISSN 2518-6558 (Print)

\begin{tabular}{|l|c|c|c|c|}
\hline $\begin{array}{l}\text { Abuse of the assets of the } \\
\text { institution or company } \\
\text { through embezzlement, } \\
\text { fraud and corruption } \\
\text { workers. }\end{array}$ & 4 & 5 & 4.3617 & .48569 \\
\hline $\begin{array}{l}\text { The use of creative } \\
\text { accounting and earning } \\
\text { management through the } \\
\text { abuse of flexibility in } \\
\text { accounting principles and } \\
\text { standards }\end{array}$ & 2 & 5 & 3.9149 & .65374 \\
\hline $\begin{array}{l}\text { Mislead the financial } \\
\text { statements through the } \\
\text { complicity of the external } \\
\text { auditor. }\end{array}$ & 2 & 5 & 3.9149 & .65374 \\
\hline $\begin{array}{l}\text { Informative trade } \\
\text { Abuse of Administrative } \\
\text { position for personal } \\
\text { benefits. }\end{array}$ & 3 & 5 & 4.1064 & .78668 \\
\hline $\begin{array}{l}\text { Financing election } \\
\text { campaigns from } \\
\text { established or company } \\
\text { funds }\end{array}$ & 3 & 5 & 4.1915 & .57628 \\
\hline $\begin{array}{l}\text { Provide guidance and } \\
\text { bribery in exchange for }\end{array}$ & 4 & 5 & 4.1915 & \\
\hline
\end{tabular}




\section{QALAAI ZANISTSCIENTIFIC JOURNAL}

A Scientific Quarterly Refereed Journal Issued by Lebanese French University - Erbil, Kurdistan, Iraq

Vol. (5), No (1), Winter 2020

ISSN 2518-6566 (Online) - ISSN 2518-6558 (Print)

\begin{tabular}{|l|c|c|c|c|}
\hline $\begin{array}{l}\text { covering up issues of fraud } \\
\text { and corruption }\end{array}$ & & & & \\
\hline Tax evasion violations & 4 & 5 & 4.3617 & .48569 \\
\hline Bad loan policy & 4 & 5 & 4.1915 & .39773 \\
\hline Money laundering cases & 3 & 5 & 4.1064 & .66705 \\
\hline Valid N (list wise) & 47 & & & \\
\hline
\end{tabular}

Table (2) show that the answers to the questionnaire questions (

Q2,

Q3 and Q4) ranged from the number two (disagree) and number five (totally agree), and questions (Q5, Q6 and Q10) ranged from the number three (Not sure) and number five (totally agree), and the rest of the questions ranged from the number four (agree) and number five (totally agree). The first and eighth questions have a higher average agreement reached (4.3617), followed by the (Q6, Q7 and Q9) questions with an average agreement reached (4.1915), while the (4) question is in ranked last with an average agreement of (3.8298). The rest of the questions are close and range between them.

The Second variable: Factors that impede the use of Forensic Accounting to detect and combat corruption and financial fraud practices in the Kurdistan Region of Iraq: The arithmetic means of each of the equation from questionnaire study evaluated by Likert scale, on this basis, the level question means according to the importance and the degree of agreement with the hypothesis of the research and summarized in the following table: 


\section{QALAAI ZANISTSCIENTIFIC JOURNAL}

A Scientific Quarterly Refereed Journal Issued by Lebanese French University - Erbil, Kurdistan, Iraq

Vol. (5), No (1), Winter 2020

ISSN 2518-6566 (Online) - ISSN 2518-6558 (Print)

Descriptive Statistics for Second variable

\begin{tabular}{|c|c|c|c|c|}
\hline Questions & Minimum & Maximum & Mean & Std. Deviation \\
\hline $\begin{array}{l}\text { Lack of experts specialized } \\
\text { in Forensic Accounting in } \\
\text { the Kurdistan Region }\end{array}$ & 3.00 & 5.00 & 4.1915 & .57628 \\
\hline $\begin{array}{l}\text { Use Forensic Accounting } \\
\text { techniques are expensive }\end{array}$ & 2.00 & 5.00 & 3.6809 & .78315 \\
\hline $\begin{array}{l}\text { Weak analysis of data for } \\
\text { Forensic Accounting in the } \\
\text { Kurdistan Region. }\end{array}$ & 3.00 & 5.00 & 4.0213 & .44180 \\
\hline $\begin{array}{l}\text { Weak mechanisms to } \\
\text { support the role of the } \\
\text { prosecution in corruption } \\
\text { cases in the Kurdistan } \\
\text { Region }\end{array}$ & 3.00 & 5.00 & 3.9362 & .52768 \\
\hline $\begin{array}{l}\text { Lack of awareness of the } \\
\text { importance of Forensic } \\
\text { Accounting in the } \\
\text { Kurdistan Region. }\end{array}$ & 4.00 & 5.00 & 4.1915 & .39773 \\
\hline $\begin{array}{l}\text { Weakness of modern } \\
\text { means and techniques in } \\
\text { Forensic Accounting in the } \\
\text { Kurdistan Region. }\end{array}$ & 3.00 & 5.00 & 3.8511 & .72167 \\
\hline
\end{tabular}




\section{QALAAI ZANISTSCIENTIFIC JOURNAL}

A Scientific Quarterly Refereed Journal Issued by Lebanese French University - Erbil, Kurdistan, Iraq

Vol. (5), No (1), Winter 2020

LF U

ISSN 2518-6566 (Online) - ISSN 2518-6558 (Print)

\begin{tabular}{|c|c|c|c|c|}
\hline $\begin{array}{l}\text { Weak Forensic Accounting } \\
\text { infrastructure in the } \\
\text { Kurdistan Region } n\end{array}$ & 3.00 & 5.00 & 4.2766 & .61510 \\
\hline $\begin{array}{l}\text { Lack of educational } \\
\text { curricula for Forensic } \\
\text { Accounting in the } \\
\text { Kurdistan Region. }\end{array}$ & 3.00 & 5.00 & 4.3617 & .64016 \\
\hline $\begin{array}{l}\text { Lack of special legal } \\
\text { materials for Forensic } \\
\text { Accounting is in the } \\
\text { Kurdistan Region }\end{array}$ & 3.00 & 5.00 & 4.0213 & .73690 \\
\hline $\begin{array}{l}\text { Lack of training in the field } \\
\text { of Forensic Accounting in } \\
\text { the Kurdistan Region }\end{array}$ & 4.00 & 5.00 & 4.2766 & .45215 \\
\hline
\end{tabular}

Valid N (list wise)

47

Table (3) show that the answers to the questionnaire second question ranged from the number two and number five, and questions ( $Q 1, Q_{3}, Q_{4}, Q_{6}, Q_{7}, Q_{8}$ and $Q 9$ ) ranged from the number three and number five, and the rest of the questions ranged from the number four and number five. The eighth question has a higher average agreement reached (4.3617), followed by the ( $\mathrm{Q} 7$ and 10) questions with an average agreement reached (4.2766), while the (2) question is in ranked last with an average agreement of (3.6809). The rest of the questions are close and range between them.

\section{3: Test reliability coefficient (consistency):}




\section{QALAAI ZANISTSCIENTIFIC JOURNAL}

A Scientific Quarterly Refereed Journal Issued by Lebanese French University - Erbil, Kurdistan, Iraq

Vol. (5), No (1), Winter 2020

LF U

ISSN 2518-6566 (Online) - ISSN 2518-6558 (Print)

Of the basic elements of the validity of relying on the results of the questionnaire tested in terms of reliability coefficient, which means the stability of scale and lack of contradiction with itself (Answers stability of the respondents and not the random use in the selection of the answer), that is, it gives the same results if re-applied to the same sample. On this basis it will be used Cronbach's alpha coefficient. To measure the consistency with sincerity (which represents the root of the reliability coefficient) questionnaire for two variables and summarized by the following table:

Table (4)

Reliability Statistics
Variable
Cronbach's Alpha
Validity
$\mathrm{N}$ of Items

First

0.755

0.8689

10

Second

0.867

0.9311

10

The reliability coefficient Cronbach's alpha for two variables of questionnaire for the measurement tool has a high degree of consistency and the truth because it is greater than $60 \%$ and validity greater than $80 \%$, since there is an internal consistency of the questions the questionnaire for two variables.

\section{4: Test hypotheses of the study:}

The study covered the test two hypotheses, as follows:

\section{First hypotheses:}




\section{QALAAI ZANISTSCIENTIFIC JOURNAL}

A Scientific Quarterly Refereed Journal Issued by Lebanese French University - Erbil, Kurdistan, Iraq

Vol. (5), No (1), Winter 2020

ISSN 2518-6566 (Online) - ISSN 2518-6558 (Print)

$H_{0}$ : There is no correlation between use of the Forensic Accounting and the detection and combating of the following corruption and financial fraud practices in the Kurdistan Region of Iraq.

$H_{1}$ : There is correlation between use of the Forensic Accounting and the detection and combating of the following corruption and financial fraud practices in the Kurdistan Region of Iraq.

Will be here to test there is important for correlation between use of the Forensic Accounting and the detection and combating of the following corruption and financial fraud practices in the Kurdistan Region of Iraq, by testing the importance of the means to the questionnaire questions which were answered by the (47) Researched according to Likert scale depending on the extent of their agreement with the hypothesis of the research and specifically test arithmetic mean equal to the (3) of the respondents (because mean of Likert equal to 3 ) against the arithmetic mean is greater than the number (3), and on this basis test was used t-test to one sample under a significance level (0.05), It summarized the results in the following table:

\section{Table (5)}

\section{One-Sample -t- test for first hypotheses}

\begin{tabular}{ccccccc}
\hline \multicolumn{7}{c}{ Mean test value $=3$} \\
Mean & value & tabulated & calculated & Error Mean & $\begin{array}{c}\text { Mean } \\
\text { Difference }\end{array}$ & Result \\
\hline 4.117 & 0.000 & 1.96 & 22.014 & 0.0507 & 1.117 & Sig. \\
\hline \hline
\end{tabular}




\section{QALAAI ZANISTSCIENTIFIC JOURNAL}

A Scientific Quarterly Refereed Journal Issued by Lebanese French University - Erbil, Kurdistan, Iraq

Vol. (5), No (1), Winter 2020

ISSN 2518-6566 (Online) - ISSN 2518-6558 (Print)

Table (4) show that mean of the agreement with the hypothesis equal to (4.117), the largest mean by Likert scale (1.117) while the $p$-value equal to $(0.000)$ which is less than the level of significance of $5 \%$ (t-calculated was $(22.014)$ which is greater than the t-tabulated value (1.96)) which means rejection of the null hypothesis and accept the alternative hypothesis, that's mean there is correlation between use of the Forensic Accounting and the detection and combating of the following corruption and financial fraud practices in the Kurdistan Region of Iraq, by sample opinions surveyed and tested.

\section{Second hypotheses:}

$H_{0}$ : There is no correlation between Factors that impede the use of Forensic Accounting to detect and combat corruption and financial fraud practices in the Kurdistan Region of Iraq.

$H_{1}$ : There is correlation between Factors that impede the use of Forensic Accounting to detect and combat corruption and financial fraud practices in the Kurdistan Region of Iraq.

Will be here to test there is important for correlation Factors that impede the use of Forensic Accounting to detect and combat corruption and financial fraud practices in the Kurdistan Region of Iraq, by testing the importance of the means to the questionnaire questions which were answered by the (47) Researched according to Likert scale depending on the extent of their agreement with the hypothesis of the research and specifically test arithmetic mean equal to the (3) of the respondents against the arithmetic mean is greater than the number (3), and on this basis test was used t-test to one sample under a significance level (0.05), It summarized the results in the following table:

\section{Table (6)}




\section{QALAAI ZANISTSCIENTIFIC JOURNAL}

A Scientific Quarterly Refereed Journal Issued by Lebanese French University - Erbil, Kurdistan, Iraq

Vol. (5), No (1), Winter 2020

ISSN 2518-6566 (Online) - ISSN 2518-6558 (Print)

One-Sample -t- test for second hypotheses

Mean test value $=3$

\begin{tabular}{ccccccc}
\hline & $\mathrm{P}$ & $\mathrm{t}$ & $\mathrm{t}$ & Standard & & Result \\
Mean & value & tabulated & calculated & Error Mean & Mean Difference & \\
\hline 4.0809 & 0.000 & 1.96 & 18.215 & 0.05934 & 1.0809 & Sig. \\
\hline \hline
\end{tabular}

Table (6) show that mean of the agreement with the hypothesis equal to (4.0809), the largest mean by Likert scale (1.0809) while the $p$-value equal to $(0.000)$ which is less than the level of significance of $5 \%$ ( $t$-calculated was (18.215) which is greater than the t-tabulated value (1.96)) which means rejection of the null hypothesis and accept the alternative hypothesis, that's mean there is correlation between Factors that impede the use of Forensic Accounting to detect and combat corruption and financial fraud practices in the Kurdistan Region of Iraq, by sample opinions surveyed and tested.

\section{Conclusion (Result)}

The researchers reached the following results:

1. There is a role Forensic Accounting in combating fraud and financial corruption in the Kurdistan Region

2. There are many factors that hinder the application of Forensic Accounting in the Kurdistan Region.

3. Forensic Accounting aims to analyze and evaluate commercial transactions, investigate fraud and reduce it by developing fraud prevention strategies, taking into account weaknesses in the system of internal control and procedures. 
4. The areas of Forensic Accounting include supporting and directing judicial consultations, providing expertise in financial matters, and proving or executing fraud cases.

\section{$\underline{\text { Recommendations }}$}

In light of the previous results, the following recommendations can be made:

1. In view of the importance of Forensic Accounting, therefore, researchers recommend increasing interest in it in the school curriculum and incorporating this aspect in accounting education so that the graduate to be familiar with it.

2. The necessity for the Kurdistan Regional Government to build an effective monitoring system based on Forensic Accounting services that takes it upon itself to preserve both the rights and the financial authority

3. Increasing interest in Forensic Accounting because of its role in combating evasion of all kinds.

4. Establishing scientific and practical qualification programs in the areas of Forensic Accounting in combating pervasive financial fraud in the Kurdistan Region.

\section{References}

Akyel, N. (2012). Forensic accounting training: A proposal for Turkey. ProcediaSocial and Behavioral Sciences, 55, 77-86.

Al-Sultan, I. I. A., Sabri, J., \& Mardan, W. A. (2015). The reflection of corrupted government on poverty: Iraq case.Journal of Advanced Social Research, 5(3), 1-12.

Alabdullah, T. T. Y., Alfadhl, M. M. A., Yahya, S., \& Rabi, A. M. A. (2014). The role of forensic accounting in reducing financial corruption: A study in Iraq. International Journal of Business and Management, 9(1), 26. 
Avnimelech, G., Zelekha, Y., \& Sharabi, E. (2014). The effect of corruption on entrepreneurship in developed vs non-developed countries. International Journal of Entrepreneurial Behavior \& Research, 20(3), 237262.

Bardhan, P. (1997). Corruption and development: A review of issues. Journal of Economic Literature, 35(3), 1320-1346.

Bhasin, M. L. (2015). Contribution of forensic accounting to corporate governance: An exploratory study of an Asian country. International Business Management, 10(4), 2016.

Brennan, N. M., \& Solomon, J. (2008). Corporate governance, accountability and mechanisms of accountability: an overview. Accounting, Auditing \& Accountability Journal, 21(7), 885-906.

Cormier, D., \& Gordon, I. M. (2001). An examination of social and environmental reporting strategies. Accounting, Auditing \& Accountability Journal, 14(5), 587-616.

Crumbley D. L. (1995). Forensic accountants appearing in the literature. New Accountant, 10(7), 25.

Crumbley, D. L. (2003). Forensic and Investigative Accounting. CCH Publishing. d'Agostino, G., Dunne, J. P., \& Pieroni, L. (2016). Government spending, corruption and economic growth. World Development, 84, 190-205.

De Rosa, D., Gooroochurn, N., \& Gorg, H. (2010). Corruption and productivity: Firm-level evidence from the BEEPS survey. The World Bank.

Gaviria, A. (2002). Assessing the effects of corruption and crime on firm performance: Evidence from Latin America. Emerging Markets Review, 3(3), 245-268.

Gray, R., Kouhy, R., \& Lavers, S. (1995). Corporate social and environmental reporting: A review of the literature and a longitudinal study of UK disclosure. Accounting, Auditing, and Accountability Journal, 8(2), 47-77.

Habib, M., \& Zurawicki, L. (2002). Corruption and foreign direct investment. Journal of International Business Studies, 33(2), 291-307.

Hadi, A. M., Abed, A. R., \& Kadim, H. O. (2018). The Role of Forensic Accounting and Its Relationship with Taxation System in Iraq. Academy of Accounting and Financial Studies Journal, 22(4), 1-10.

Kasum, A. (2009). The relevance of forensic accounting to financial crimes in private and public sectors of third world economies: A study from 


\section{QALAAI ZANISTSCIENTIFIC JOURNAL}

A Scientific Quarterly Refereed Journal Issued by Lebanese French University - Erbil, Kurdistan, Iraq

Vol. (5), No (1), Winter 2020

ISSN 2518-6566 (Online) - ISSN 2518-6558 (Print)

Nigeria. In Proceedings of The 1st International Conference on Governance Fraud Ethics and Social Responsibility.

Kranacher, M. J., \& Riley, R. (2019). Forensic accounting and fraud examination. John Wiley \& Sons.

Magness, V. (2006). Strategic posture, financial performance and environmental disclosure: An empirical test of legitimacy theory. Accounting, Auditing \& Accountability Journal, 19(4), 540-563.

Maxime, A. (2013). "Iraq: Overview of corruption and anti-corruption", Transparency International Anti-Corruption Resource Center, May 2013, p. 3.

Nwanyanwu, L. A. (2018). Accountants' ethics and fraud control in Nigeria: The emergence of a fraud control model. Journal of Accounting, Finance and Auditing Studies, 4(1), 130-150.

Okoye, E. I. (2009). The role of forensic accounting in fraud investigation and litigation support. The Nigerian Academic Forum, 17(1), November 2009. Available at SSRN: https://ssrn.com/abstract=1788822.

Rubin, M. (2018). The continuing problem of KRG corruption. In Gunter, M. M. (2018) Routledge Handbook on the Kurds. Routledge.

Wang, J., Lee, G., \& Crumbley, D. L. (2016). Current availability of forensic accounting education and state of forensic accounting services in Hong Kong and mainland China. Journal of Forensic and Investigative Accounting, 8(3), 515-534.

Whiting, R. H., \& Woodcock, J. (2011). Firm characteristics and intellectual capital disclosure by Australian companies. Journal of Human Resource Costing \& Accounting, 15(2), 102-126.

Zysman, A. (2004). Forensic accounting demystified, world investigators network standard practice for investigative and forensic accounting engagements. Canadian Institute of Chartered Accountant. 


\section{QALAAI ZANISTSCIENTIFIC JOURNAL \\ A Scientific Quarterly Refereed Journal Issued by Lebanese French University - Erbil, Kurdistan, Iraq \\ Vol. (5), No (1), Winter 2020 \\ ISSN 2518-6566 (Online) - ISSN 2518-6558 (Print)}

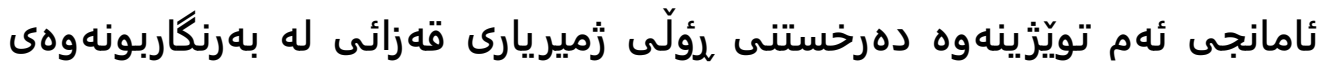

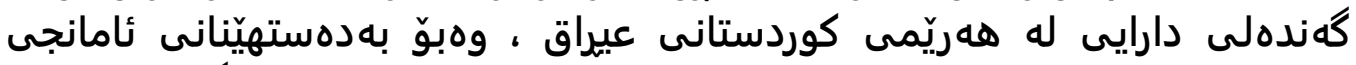

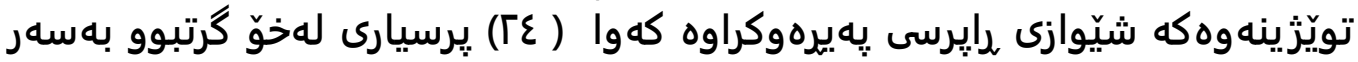

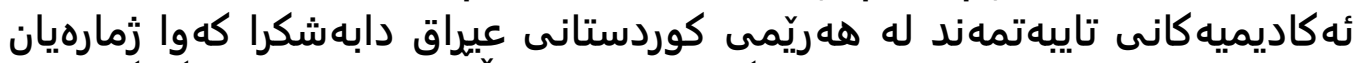
(عV)

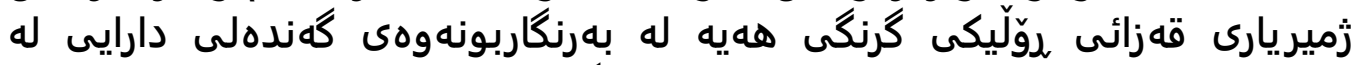

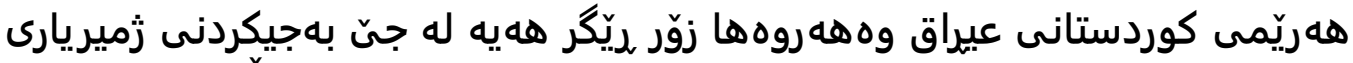

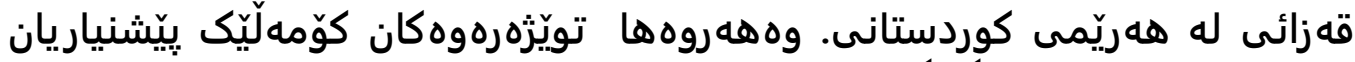

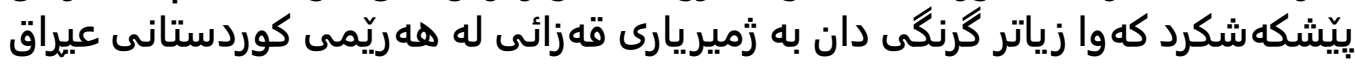

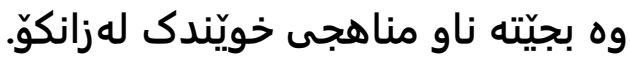

مكافحة الغش والفساد المالي من خلال ممارسات المحاسبة القضائية في اقليم كوردستان العراق افه

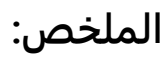

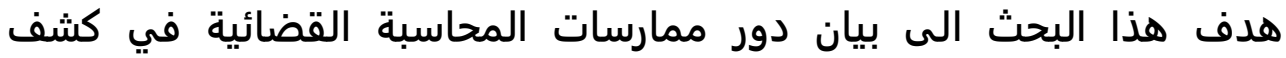

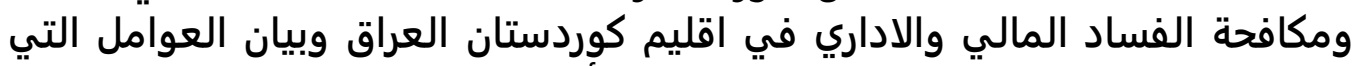

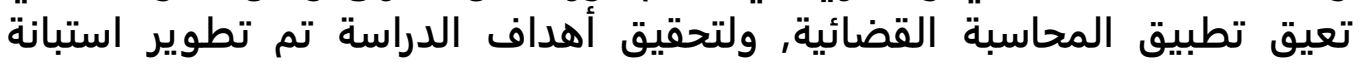

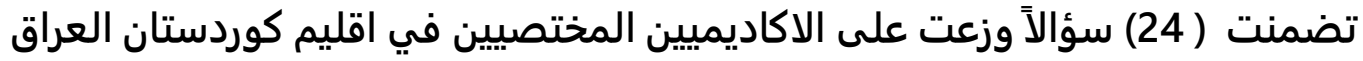

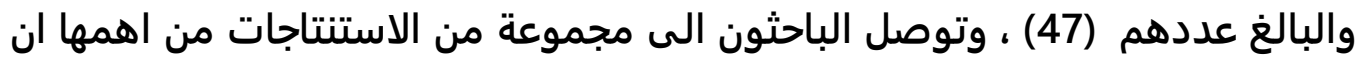

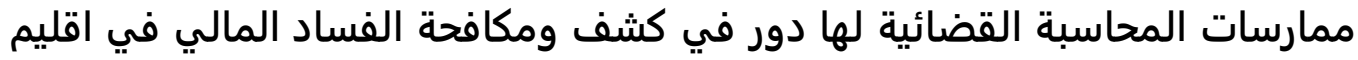

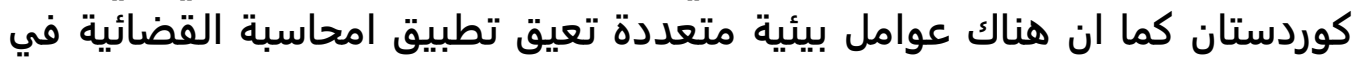

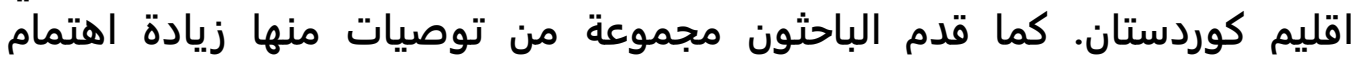

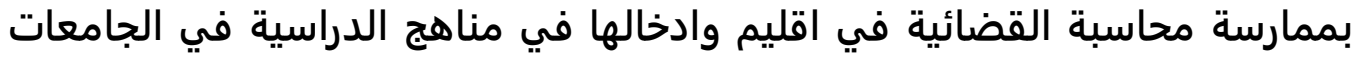
الاقليم حتى يتعرفوا على اهمية ممارسات المحاسبة القضائية واهدائية فالفافية الفها. 